\title{
Reclassification of salt-water Bdellovibrio sp. as Bacteriovorax marinus sp. nov. and Bacteriovorax litoralis sp. nov.
}

\author{
Marcie L. Baer, ${ }^{1} \dagger$ Jacques Ravel, ${ }^{2} \ddagger$ Silvia A. Piñeiro, ${ }^{1}$ Diana Guether-Borg \\ and Henry N. Williams ${ }^{1}$ \\ ${ }^{1}$ Department of Biomedical Sciences, University of Maryland at Baltimore, 666 W. Baltimore \\ Street, Baltimore, MD 21201, USA \\ ${ }^{2}$ Center of Marine Biotechnology, University of Maryland Biotechnology Institute, \\ 701 East Pratt Street, Baltimore, MD 21202, USA
}

Correspondence

Marcie L. Baer

mlbaer@ship.edu

\begin{abstract}
Bdellovibrios are unique, predatory bacteria with an intraperiplasmic growth and multiplication phase within their prey, which consists of many Gram-negative bacteria. Until recently, all bacteria that exhibited these traits were included in the genus Bdellovibrio. However, analysis of $16 \mathrm{~S}$ rDNA sequences and other studies have demonstrated substantial genotypic, phenotypic and ecotypic diversity among the organisms in this genus (Baer et al., 2000; Snyder et al., 2002). This has resulted in reclassification of Bdellovibrio stolpii and Bdellovibrio starrii into the newly constructed genus Bacteriovorax (Baer et al., 2000). In this study, examination of marine isolates of Bdellovibrio (designated $\mathrm{SJ}^{\top}, \mathrm{AQ}$ and $\mathrm{JS}^{\top}{ }^{\top}$ ) has revealed them to be related more closely to the newly designated genus Bacteriovorax. Phylogenetic analysis of $16 \mathrm{~S}$ rRNA gene sequences revealed that marine isolates $\mathrm{SJ} \mathrm{J}^{\top}, \mathrm{AQ}$ and $\mathrm{JS} 5^{\top}$ clustered in a separate clade from Bdellovibrio bacteriovorus $100^{\top}$ as part of the clade that contains Bacteriovorax spp., indicating a much closer taxonomic relationship to the latter. DNA-DNA hybridization experiments also demonstrated $<5 \%$ similarity between Bdellovibrio bacteriovorus $100^{\top}$ and the marine isolates. Distinct differences between the salt-water group and Bdellovibrio spp. were also observed by determination of DNA $G+C$ content, salinity growth testing and antibiotic sensitivity analysis. On the basis of the results from the studies described above, it is proposed that marine isolates $\mathrm{SJ} \mathrm{J}^{\top}$

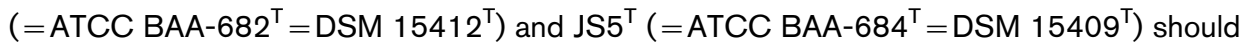
be classified within the genus Bacteriovorax as the type strains of Bacteriovorax marinus sp. nov. and Bacteriovorax litoralis sp. nov., respectively.
\end{abstract}

Bdellovibrio and Bdellovibrio-like organisms (BALO) are Gram-negative bacteria that prey uniquely upon a wide variety of susceptible, Gram-negative bacteria. They exhibit a biphasic life cycle that consists of an intraperiplasmic growth phase within their prey and a free-living, extracellular phase, in which the highly motile organisms 'hunt'

Published online ahead of print on 3 October 2003 as DOI 10.1099/ ijs.0.02458-0.

Abbreviations: BALO, Bdellovibrio and Bdellovibrio-like organisms; PD, prey-dependent; PI, prey-independent.

†Present address: Shippensburg University, Biology Department, 1871 Old Main Drive, Shippensburg, PA 17257, USA.

‡Present address: The Institute for Genomic Research, 9712 Medical Center Drive, Manassas, VA 20850, USA.

The GenBank/EMBL/DDBJ accession numbers for the 16S rRNA gene sequences of Bacteriovorax marinus $\mathrm{SJ}^{\top}$, Bacteriovorax marinus $\mathrm{AQ}$ and Bacteriovorax litoralis $\mathrm{JS5}^{\top}$ are AF084854, AF084855 and AF084859, respectively. for new cells to attack. Soon after their discovery in 1962 (Stolp \& Petzold, 1962), two groups of Bdellovibrio were recognized. The freshwater/terrestrial group can only tolerate sodium chloride concentrations of $<0.5 \%$ and is found in soil and freshwater (Varon \& Shilo, 1968). Marine or halophilic organisms require sodium chloride at concentrations of $>0.5 \%$ and are found in oceans, seas, estuaries and other salt or brackish waters (Taylor et al., 1974; Marbach et al., 1976; Williams, 1979, 1987; Williams \& Falkler, 1984; Sutton \& Besant, 1994). In addition, marine bdellovibrios have DNA G $+\mathrm{C}$ contents of $<38 \mathrm{~mol} \%$ (Schoeffield, 1990), whereas those of freshwater/terrestrial organisms range from 47 to $51 \mathrm{~mol} \%$ (Seidler et al., 1972; Marbach et al., 1976). The DNA G + C contents of members of the genus Bacteriovorax (Baer et al., 2000) that were classified previously as Bdellovibrio range from 41 to $44 \mathrm{~mol} \%$ (Seidler et al., 1972). Few studies have described the properties of the marine bdellovibrios (Taylor et al., 1974; Marbach et al., 1976; Sutton \& Besant, 1994) and these 
have typically included a limited number of characters, as traditional laboratory-based tests cannot be used to characterize the predators because they do not grow in pure culture. The most common properties that are used to distinguish the predators are those in which BALO can be grown with their prey and include salinity and temperature growth ranges and prey susceptibility patterns. Although marine and terrestrial predators are quite distinct in these properties and their DNA G + C content, they have continued to be assigned to the same genus, Bdellovibrio. This suggests, misleadingly, that they are closely related and share many similar properties. In this study, we have shown that marine and terrestrial Bdellovibrio sp. are genetically and phenotypically diverse, as shown by comparison of $16 \mathrm{~S}$ rDNA sequences, DNA-DNA similarity studies, determination of DNA G + C content and culture-based methods. We report the first evaluation of the taxonomic classification for three marine isolates $\left(\mathrm{SJ}^{\mathrm{T}}, \mathrm{AQ}\right.$ and $\mathrm{JS}^{\mathrm{T}}{ }^{\mathrm{T}}$ ) of Bdellovibrio.

Strains $\mathrm{AQ}, \mathrm{SJ}^{\mathrm{T}}$ and $\mathrm{JS}^{\mathrm{T}}$ were isolated by Schoeffield (1990) from water samples from the National Aquarium in Baltimore, St John's Island in the Caribbean and the Chesapeake Bay estuary, respectively. Marine, prey-dependent (PD) strains were grown in prey/sea water (PS) medium with Vibrio parahaemolyticus P-5 (Williams, 1987; Schoeffield, 1990; Williams et al., 1995), whilst freshwater/ terrestrial PD strains were grown in dilute nutrient broth (DNB) medium (Starr \& Seidler, 1971) with Escherichia coli ML35. Prey-independent (PI) mutants were isolated from wild-type PD cultures by using the methods described by Seidler \& Starr (1969) for freshwater/terrestrial strains or by Schoeffield (1990) for marine strains. Suspensions of PD isolates were prepared by filtration through a $0.3 \mu \mathrm{m}$ filter (Millipore) for marine strains or a $0.45 \mu \mathrm{m}$ filter (Nucleopore) for freshwater/terrestrial strains. After centrifugation at $27000 \mathrm{~g}$ for $60 \mathrm{~min}$, predator cells were resuspended in sterile $70 \%$ artificial sea water (ASW) or DNB for marine and freshwater/terrestrial strains, respectively. Predator concentrations (cells $\mathrm{ml}^{-1}$ ) were determined by the acridine orange direct-count method (Hobbie et al., 1977). Bdellovibrio genomic DNA was purified by $\mathrm{CsCl}$ density gradients that were prepared as described by Ausubel et al. (1987). 16S rRNA genes were amplified by using primers 8-27F (5' -AGAGTTTGATCCTGGCTCAG$3^{\prime}$, modified from FD1) (Weisburg et al., 1991) and 1492R (5'-GGTTACCTTGTTACGACTT-3'; Weisburg et al., 1991; Reysenbach et al., 1992). Both strands of the resulting amplicon from each isolate were sequenced completely and aligned with sequences that were published previously for members of the genus Bacteriovorax and closely related micro-organisms (Baer et al., 2000) by using the PHYDIT program (Chun, 1995). Evolutionary trees were inferred by using four treeing algorithms that are implemented in the PHYLIP package: Fitch-Margoliash (Fitch \& Margoliash, 1967), maximum-likelihood (Felsenstein, 1981; Olsen et al., 1994), maximum-parsimony (Kluge \& Farris, 1969) and neighbour-joining (Saitou \& Nei, 1987). Evolutionary distance matrices for the neighbour-joining and FitchMargoliash methods were generated by the method of Jukes \& Cantor (1969). The final unrooted tree (Fig. 1) was evaluated by neighbour-joining bootstrap analyses, based on 1000 reassembled datasets. 16S rRNA gene sequences for isolates $\mathrm{SJ}^{\mathrm{T}}$ (GenBank accession no. AF084854), AQ (AF084855) and JS5 ${ }^{\mathrm{T}}$ (AF084859) were compared with the sequences for Bdellovibrio bacteriovorus $100^{\mathrm{T}}$ (AF084850, a gift from J. Tudor), Bacteriovorax stolpii $\mathrm{Uki}^{\mathrm{T}}=\mathrm{ATCC}$ $27052^{\mathrm{T}}(\mathrm{M} 34125)$ and Bacteriovorax starrii $\mathrm{A} 3.12^{\mathrm{T}}=\mathrm{ATCC}$ $15145^{\mathrm{T}}$ (AF084852) in GenBank. Subsequently, a similarity analysis was performed to compare the BALO $16 \mathrm{~S}$ rDNA sequences with those of related taxa in the $\delta$-Proteobacteria. The level of similarity found between 1155 nucleotide sites of Bdellovibrio bacteriovorus $100^{\mathrm{T}}$ and marine isolates $\mathrm{SJ}^{\mathrm{T}}$,

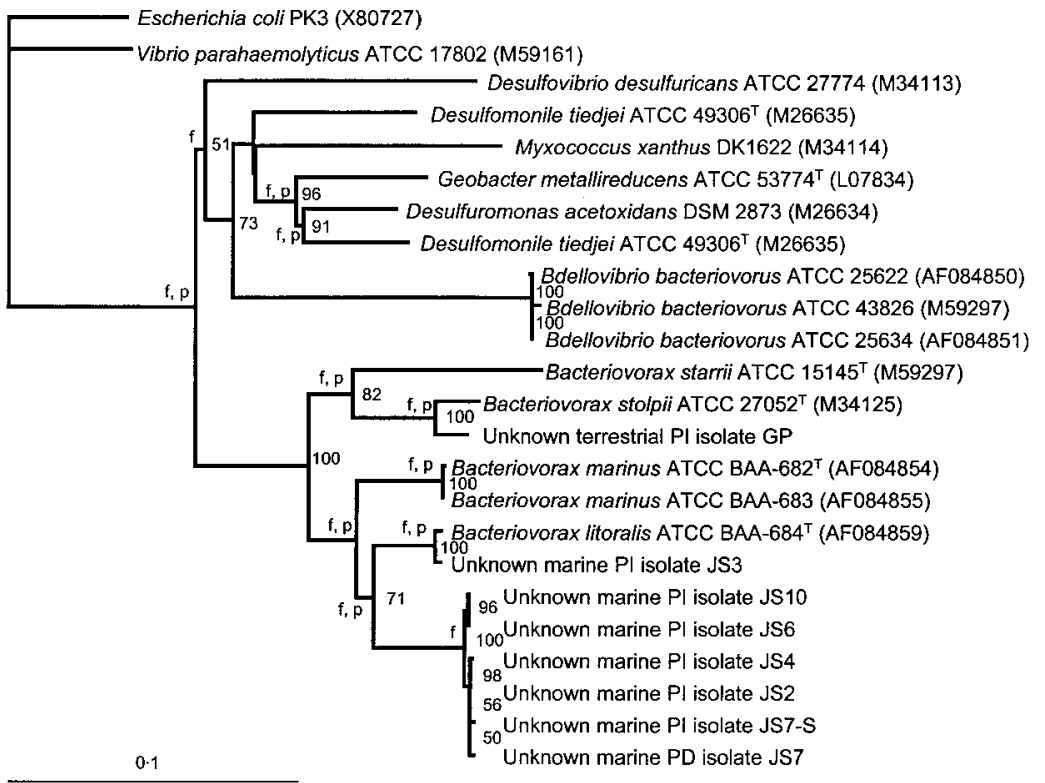

Fig. 1. Neighbour-joining phylogenetic tree, demonstrating the relationship between marine and terrestrial Bdellovibrio isolates. Values represent stability of branches (\%), based on 1000 resamplings. Branches that are the same using the Fitch-Margoliash $(f)$ and DNA parsimony ( $p$ ) analyses are marked. 
AQ and $\mathrm{JS5}^{\mathrm{T}}$ was $81 \cdot 7,81 \cdot 8$ and $81 \cdot 5 \%$, respectively. Bdellovibrio bacteriovorus $100^{\mathrm{T}}$ had greater similarity to other genera in the $\delta$-Proteobacteria, such as Desulfovibrio desulfuricans, $82 \cdot 1 \%$; Myxococcus xanthus, $83.5 \%$; Geobacter metallireducens, $84 \cdot 7 \%$ and Desulfomonile tiedjei, $85 \cdot 1 \%$. In contrast, $16 \mathrm{~S}$ rDNA sequence similarity between the marine isolates $\left(\mathrm{SJ}^{\mathrm{T}}\right.$ and $\left.\mathrm{JS}^{\mathrm{T}}\right)$ and Bacteriovorax stolpii $\mathrm{Uki}^{\mathrm{T}}$ was significantly higher $(91 \cdot 0$ and $91 \cdot 1 \%$, respectively). Similarity values between the marine isolates and Bacteriovorax starrii $\mathrm{A} 3.12^{\mathrm{T}}$ ranged from $88.6\left(\mathrm{JS}^{\mathrm{T}}\right)$ to $88 \cdot 8\left(\mathrm{SJ}^{\mathrm{T}}\right) \%$. Similarity between $\mathrm{SJ}^{\mathrm{T}}$ and $\mathrm{JS}^{\mathrm{T}}$ was determined to be much higher ( $>93 \%$ ). The distant relationship between the marine isolates and other Bdellovibrio spp. is apparent from the unrooted evolutionary tree (Fig. 1). The marine isolates did not cluster with the Bdellovibrio bacteriovorus clade, but within a larger group that is divided into two branches, one of which contains Bacteriovorax spp. and the second the marine strains. Data generated by the maximum-parsimony, maximum-likelihood and Fitch-Margoliash methods produced similar results.

Genomic relatedness of each isolate was investigated by DNA-DNA hybridization by using a direct binding assay (Johnson, 1988) with $\left[\alpha^{32} \mathrm{P}\right] \mathrm{dCTP}-$ labelled probes on membranes (Denhardt, 1966). Intensity of hybridization was measured by using a STORM 840 PhosphoImager (Perkin-Elmer). Reciprocal experiments were performed for each pair of strains. DNA-DNA hybridization results revealed low similarity $(<3.5 \%)$ between Bdellovibrio bacteriovorus $100^{\mathrm{T}}$ [and also strains 109J (a gift from M. Thomashow) and 2484Se2 (=ATCC 25635)] and marine isolate $\mathrm{SJ}^{\mathrm{T}}$. Bdellovibrio bacteriovorus strains $\mathrm{E}$ (=ATCC 25634) and Ox9-2 (=ATCC 25635) showed a slightly higher degree of DNA-DNA similarity to $\mathrm{SJ}^{\mathrm{T}}(5 \cdot 7$ and $5 \cdot 2 \%$, respectively). Marine isolate $\mathrm{JS}^{\mathrm{T}}{ }^{\mathrm{T}}$ also demonstrated low similarity $(<3.6 \%)$ to all Bdellovibrio bacteriovorus strains $\left(100^{\mathrm{T}}, 109 \mathrm{~J}, \mathrm{Ox} 9-2, \mathrm{E}\right.$ and $\left.2484 \mathrm{Se} 2\right)$. A previous study (Baer et al., 2000) demonstrated low similarity $(<4 \%)$ between strains of Bdellovibrio bacteriovorus and the Bacteriovorax species $(<3-4 \%)$. Isolate $\mathrm{SJ}^{\mathrm{T}}$ demonstrated slightly higher similarity to Bacteriovorax stolpii $\mathrm{Uki2}^{\mathrm{T}}$ and Bacteriovorax starrii $\mathrm{A} 3.12^{\mathrm{T}}(7 \cdot 7$ and $3 \cdot 5 \%$, respectively). DNA-DNA similarity between $\mathrm{JS}^{\mathrm{T}}$ and Bacteriovorax species was slightly lower $(4.9$ and $3 \cdot 1 \%$, respectively).

The DNA G $+\mathrm{C}$ content of PI isolates $\mathrm{AQ}$ and $\mathrm{SJ}^{\mathrm{T}}$ was determined by thermal melting curves (Schoeffield, 1990). The HPLC method was used for PD isolate JS5 ${ }^{\mathrm{T}}$ (Mesbah et al., 1989). The DNA G + C contents of $\mathrm{SJ}^{\mathrm{T}}, \mathrm{AQ}$ and $\mathrm{JS5}^{\mathrm{T}}$ were $37 \cdot 7,38 \cdot 3$ and $37 \cdot 8 \mathrm{~mol} \%$, respectively; these values are lower than the range of $47-51 \mathrm{~mol} \%$ that has been reported for freshwater/terrestrial Bdellovibrio (Seidler et al., 1972; Marbach et al., 1976) and also than the range for the genus Bacteriovorax (41-44 mol\%) (Seidler et al., 1972).

Comparisons of the phenotypic properties of the marine and terrestrial Bdellovibrio strains confirmed the differences that were revealed by molecular methods. The enzymic reactions of each $\mathrm{PD}$ isolate and its $\mathrm{PI}$ derivative were examined by using the API ZYM test system (bioMérieux), according to the manufacturer's recommendations. The results reported in Table 1 were consistent for both PI and PD isolates, except where noted. Of the 19 enzyme substrates against which the isolates were tested, only four (valine and cystine aminopeptidases, trypsin and chymotrypsin) yielded differential reactions (Table 1). Reactions to valine and chymotrypsin differentiated salt-water from freshwater Bdellovibrio. A positive reaction for cystine differentiated isolates $\mathrm{SJ}^{\mathrm{T}}$ and 109J (negative). Isolates AQ and JS5 ${ }^{\mathrm{T}}$ yielded variable results. Lack of trypsin activity distinguished the estuarine isolate, $\mathrm{JS5}^{\mathrm{T}}$, from all other isolates, which were positive.

Antibiogram profiles were generated for PD strains by using the double-agar overlay technique (Stolp \& Starr, 1963) and, for PI strains, by the typical spread-plate method, as described by Guether \& Williams (1993). Freshwater/terrestrial PD strains were tested on dilute (1/10) PYE (peptone/yeast extract) medium with E. coli ML35 as prey. For marine Bdellovibrio, dilute (1/10) SWYE (sea water/yeast extract/agar) medium was used with the prey, V. parahaemolyticus P-5. A second prey, Pseudomonas fluorescens, was used for testing both marine and terrestrial PD strains. The antibiotics tested are listed in Table 1. A resistant reaction was observed by growth of the predators up to the disc, as indicated by clearing or lysis of the prey lawn. In a sensitive reaction, the predators did not grow to the edge of the discs and there remained a turbid zone of prey cell growth. Control tests with only the prey lawn and without the predators were included. Tests were repeated three times for each isolate. The results reported in this study represent antibiotic susceptibilities that were consistent for both PD and PI isolates. The results revealed that susceptibility to methicillin yielded a clear distinction between marine (resistant) and freshwater (susceptible) BALO strains. Kanamycin was observed to distinguish between isolates $\mathrm{SJ}^{\mathrm{T}}$ (susceptible) and $\mathrm{SS}^{\mathrm{T}}$ (resistant). No difference was found between the pattern susceptibilities of isolates $\mathrm{SJ}^{\mathrm{T}}$ and $\mathrm{AQ}$ (Table 1).

The temperature growth range for each isolate was determined. For PD strains, double-agar overlay plates were incubated in humidified chambers for up to 2 weeks at 10 , $15,20,25,30,35$ and $40^{\circ} \mathrm{C}$. Plates incubated at 10 and $15^{\circ} \mathrm{C}$ were incubated for up to 2 months. For these plates, the prey cell concentration in the top agar was increased to compensate for the slower growth rate of the prey. Mean plaque count and standard deviation (SD) were calculated from three replicate experiments. For testing PI strains, suspensions were prepared in sterile $70 \%$ ASW for marine isolates and sterile distilled water for freshwater/terrestrial strains. Aliquots of the suspensions $(0 \cdot 1 \mathrm{ml})$ were spreadplated onto SWYE agar or PYE agar. Plates were incubated under the same conditions and mean counts were calculated, as for the PD predators. The results revealed that the temperature growth range was $15-35^{\circ} \mathrm{C}$ for freshwater 
Table 1. Differential characteristics of salt-water and freshwater Bdellovibrio strains

Unless otherwise noted, all results are for PD strains and their respective PI derivatives.

\begin{tabular}{|c|c|c|c|c|}
\hline \multirow[t]{2}{*}{ Characteristic } & \multicolumn{3}{|c|}{ Salt-water isolates } & \multirow{2}{*}{$\begin{array}{l}\text { Freshwater } \\
\text { isolate 109J }\end{array}$} \\
\hline & $\mathrm{SJ}^{\mathrm{T}}$ & AQ & $\mathrm{JS5}^{\mathrm{T}}$ & \\
\hline $\mathrm{Na}^{+}$required for growth $(\geqslant 0.5 \%)$ & + & + & + & - \\
\hline DNA G $+C$ content $(\mathrm{mol} \%)$ & $37 \cdot 7^{\star}$ & $38 \cdot 3^{\star}$ & $37 \cdot 8$ & $51 \cdot 5 \dagger$ \\
\hline Growth temperature $\left({ }^{\circ} \mathrm{C}\right)$ & $15-30$ & $15-30$ & $15-35$ & $15-35$ \\
\hline \multicolumn{5}{|l|}{ Enzyme activities tested: } \\
\hline Alkaline phosphatase & + & + & + & $+\ddagger$ \\
\hline Esterase (C4) & + & + & + & $+\ddagger$ \\
\hline Esterase lipase (C8) & + & + & + & + \\
\hline Lipase $(\mathrm{C} 4)$ & $\mathrm{v} \S$ & $\mathrm{v} \S$ & - & $-末$ \\
\hline Leucine aminopeptidase & + & + & + & $+\ddagger$ \\
\hline Valine aminopeptidase & + & + & + & $-\ddagger$ \\
\hline Cystine aminopeptidase & + & $\mathrm{v} \S$ & $v \$$ & $-\ddagger$ \\
\hline Trypsin & + & + & - & $+\ddagger$ \\
\hline Chymotrypsin & - & - & - & $+\ddagger$ \\
\hline Acid phosphatase & + & + & + & $+\ddagger$ \\
\hline Phosphoamidase & + & + & + & $+\ddagger$ \\
\hline$\alpha$-Galactosidase & - & - & - & $-末$ \\
\hline$\beta$-Galactosidase & - & - & - & $-末$ \\
\hline$\beta$-Glucuronidase & - & - & - & -末 \\
\hline$\alpha$-Glucosidase & - & - & - & $-\ddagger$ \\
\hline$\beta$-Glucosidase & - & - & - & $-\ddagger$ \\
\hline$N$-Acetyl- $\beta$-glucosaminidase & $\mathrm{v} \S$ & $\mathrm{v} \S$ & $v \$$ & $-\ddagger$ \\
\hline$\alpha$-Mannosidase & - & - & - & $-\ddagger$ \\
\hline$\alpha$-Fucosidase & - & - & - & $-末$ \\
\hline \multicolumn{5}{|l|}{ Antibiotic sensitivity: } \\
\hline Methicillin $(5 \mu \mathrm{g})$ & RII & $\mathrm{R}$ & $\mathrm{R}$ & $S$ \\
\hline Ampicillin/sublactam $(20 \mu \mathrm{g})$ & S & S & S & S \\
\hline Carbenicillin $(100 \mu \mathrm{g})$ & S & S & $\mathrm{v} \S$ & S \\
\hline Kanamycin $(30 \mu \mathrm{g})$ & S & S & $\mathrm{R}$ & S \\
\hline Gentamicin $(10 \mu \mathrm{g})$ & S & S & $\mathrm{V}$ & S \\
\hline Nalidixic acid $(5 \mu \mathrm{g})$ & $\mathrm{R}$ & $\mathrm{R}$ & $\mathrm{v} \S$ & $\mathrm{R}$ \\
\hline Colistin sulphate $(10 \mu \mathrm{g})$ & $\mathrm{R}$ & $\mathrm{R}$ & $\mathrm{R}$ & $\mathrm{R}$ \\
\hline Polymyxin B (300 U) & S & S & $\mathrm{V}$ & $\mathrm{R}$ \\
\hline Vancomycin $(30 \mu \mathrm{g})$ & $\mathrm{R}$ & $\mathrm{R}$ & $\mathrm{R}$ & $\mathrm{v} \S$ \\
\hline
\end{tabular}

${ }^{\star}$ From Schoeffield (1990).

$\dagger$ From Seidler et al. (1969).

¥Only enzyme activities from PI isolates.

$\S \mathrm{V}$, Variable results observed for PD and PI strains.

IIR, Resistant to antibiotic.

SS, Susceptible to antibiotic.

strains (with a few exceptions), $15-30{ }^{\circ} \mathrm{C}$ for marine strains $\mathrm{AQ}$ and $\mathrm{SJ}^{\mathrm{T}}$ and $15-35^{\circ} \mathrm{C}$ for isolate $\mathrm{JS}^{\mathrm{T}}$ (Table 1).

Salinity growth range is not only a distinctive feature between marine and terrestrial BALO, but also among marine isolates. Those organisms that were isolated from the upper and mid-regions of the Chesapeake Bay estuary, where salinities range from 0.5 to $2 \%$, tended to grow at lower salinities than isolate $\mathrm{SJ}^{\mathrm{T}}$, which was recovered from ocean waters (salinity of approximately $3 \%$ ). Differences between ocean and estuarine isolates were also revealed by $16 \mathrm{~S}$ rDNA sequence analysis. These differences warrant the separation of these organisms into different species within the same genus.

The results of this study provide conclusive evidence that the genus Bdellovibrio consists of molecularly diverse groups of micro-organisms that are not related closely to 
each other. The use of a predatory lifestyle as the sole criterion for classification of these organisms has resulted in the inclusion of phylogenetically diverse groups within the same genus. A change in the taxonomic status of marine Bdellovibrio is clearly warranted, based on the phylogenetic 16S rDNA sequence analysis, DNA-DNA similarity results, DNA $\mathrm{G}+\mathrm{C}$ contents and phenotypic properties that are described in this investigation. Phylogenetic analysis of BALO 16S rRNA gene sequences revealed that marine isolates $\mathrm{SJ}^{\mathrm{T}}$, AQ and $\mathrm{JS}^{\mathrm{T}}$ clustered in a separate clade from Bdellovibrio bacteriovorus $100^{\mathrm{T}}$, as part of the clade that contains Bacteriovorax spp., indicating a much closer taxonomic relationship to the latter. Results from other studies confirm that all marine Bdellovibrio isolates analysed to date fall into the same clade (Snyder et al., 2002). It is appropriate, therefore, that salt-water Bdellovibrio should be reassigned to the genus Bacteriovorax. Here, we propose that marine isolates $\mathrm{SJ}^{\mathrm{T}}$ and $\mathrm{JS5}^{\mathrm{T}}$ should be moved from the genus Bdellovibrio and assigned to the genus Bacteriovorax, as the type strains of Bacteriovorax marinus sp. nov. and Bacteriovorax litoralis sp. nov., respectively. Marine strain AQ should also be placed within Bacteriovorax marinus, due to its genetic similarities to isolate $\mathrm{SJ}^{\mathrm{T}}$. However, phenotypic and biochemical differences suggest that it may be a separate strain; this requires further study.

\section{Description of Bacteriovorax marinus sp. nov.}

Bacteriovorax marinus (ma'ri.nus. L. masc. adj. marinus of the sea, marine).

Cultural, biochemical and molecular characteristics of Bacteriovorax marinus are listed in Table 1. Optimal temperature range for growth is $15-30^{\circ} \mathrm{C}$. Salinity range is 10-60 parts per thousand (p.p.t.), with optimal growth between 20 and 30 p.p.t. Resistant to methicillin, nalidixic acid, colistin sulfate and vancomycin, but susceptible to kanamycin, carbenicillin, ampicillin/sublactam, gentamicin and polymyxin B (Guether \& Williams, 1993). Enzyme activities for trypsin, alkaline phosphatase, esterase (C4), esterase lipase (C8), leucine aminopeptidase, valine aminopeptidase, acid phosphatase and phosphoamidase are detected. Closely related phylogenetically to both Bacteriovorax stolpii $\mathrm{Uki}^{\mathrm{T}}$ and Bacteriovorax starrii $\mathrm{A} 3.12^{\mathrm{T}}$, as determined by $16 \mathrm{~S}$ rDNA sequence analysis. DNA $\mathrm{G}+\mathrm{C}$ content is $37 \cdot 7-38 \cdot 3 \mathrm{~mol} \%$.

The type strain of Bacteriovorax marinus is $\mathrm{SJ}^{\mathrm{T}}$ ( = ATCC BAA $\left.-682^{\mathrm{T}}=\mathrm{DSM} 15412^{\mathrm{T}}\right)$. Isolated from the surrounding waters of St John's Island, US Virgin Islands. Reference strain is AQ.

\section{Description of Bacteriovorax litoralis sp. nov.}

Bacteriovorax litoralis (li.to.ra'lis. L. masc. adj. litoralis pertaining to the coast).

Cultural, biochemical and molecular characteristics of Bacteriovorax marinus are listed in Table 1. Optimal temperature range for growth is $15-35^{\circ} \mathrm{C}$. Salinity range is $0 \cdot 25-30$ p.p.t., with optimal growth at 5 p.p.t. Resistant to a range of antibiotics (methicillin, kanamycin, colistin sulfate and vancomycin), but susceptible to ampicillin/ sublactam (Guether \& Williams, 1993). No trypsin activity is detected (unlike Bacteriovorax marinus and Bdellovibrio bacteriovorus 109J), but enzyme activities are demonstrated for alkaline phosphatase, esterase (C4), esterase lipase (C8), leucine aminopeptidase, valine aminopeptidase, acid phosphatase and phosphoamidase. Closely related phylogenetically to both Bacteriovorax stolpii $\mathrm{Uki}^{\mathrm{T}}$ and Bacteriovorax starrii $\mathrm{A} 3.12^{\mathrm{T}}$, as determined by $16 \mathrm{~S} \mathrm{rDNA}$ sequence analysis. DNA G $+\mathrm{C}$ content is $37 \cdot 8 \mathrm{~mol} \%$.

The type strain (and only strain to date) is $\mathrm{JS}^{\mathrm{T}}$ ( $=$ ATCC BAA $\left.-684^{\mathrm{T}}=\mathrm{DSM} 15409^{\mathrm{T}}\right)$. Isolated from the gills of a crab captured on the Patuxent River, an estuary of the Chesapeake Bay.

\section{Acknowledgements}

This material is based on work that was supported by the National Science Foundation under grant no. OCE-9731055.

\section{References}

Ausubel, F. M., Brent, R., Kingston, R. E., Moore, D. D., Seidman, J. G., Smith, J. A. \& Struhl, K. (1987). Current Protocols in Molecular Biology. New York: Wiley.

Baer, M. L., Ravel, J., Chun, J., Hill, R. T. \& Williams, H. N. (2000). A proposal for the reclassification of Bdellovibrio stolpii and Bdellovibrio starrii into a new genus, Bacteriovorax gen. nov. as Bacteriovorax stolpii comb. nov. and Bacteriovorax starrii comb. nov., respectively. Int J Syst Evol Microbiol 50, 219-224.

Chun, J. (1995). Computer-assisted classification and identification of actinomycetes. PhD thesis, University of Newcastle upon Tyne, UK.

Denhardt, D. T. (1966). A membrane-filter technique for the detection of complementary DNA. Biochem Biophys Res Commun 23, 641-646.

Felsenstein, J. (1981). Evolutionary trees from DNA sequences: a maximum likelihood approach. J Mol Evol 17, 368-376.

Fitch, W. M. \& Margoliash, E. (1967). Construction of phylogenetic trees. Science 155, 279-284.

Guether, D. L. \& Williams, H. N. (1993). Antibiogram characterization of aquatic and terrestrial Bdellovibrio isolates. Abstract Q-244 presented at the 93rd General Meeting of the American Society for Microbiology, Atlanta, Georgia, USA.

Hobbie, J. E., Daley, R. J. \& Jasper, S. (1977). Use of nuclepore filters for counting bacteria by fluorescence microscopy. Appl Environ Microbiol 33, 1225-1228.

Johnson, J. L. (1988). Nucleic acids in bacterial classification. In Bergey's Manual of Systematic Bacteriology, vol. 4, pp. 2306-2309. Edited by S. T. Williams, M. E. Sharpe \& J. G. Holt. Baltimore: Williams \& Wilkins.

Jukes, T. H. \& Cantor, C. R. (1969). Evolution of protein molecules. In Mammalian Protein Metabolism, pp. 21-132. Edited by H. N. Munro. New York: Academic Press.

Kluge, A. G. \& Farris, J. S. (1969). Quantitative phyletics and the evolution of anurans. Syst Zool 18, 1-32.

Marbach, A., Varon, M. \& Shilo, M. (1976). Properties of marine bdellovibrios. Microb Ecol 2, 284-295. 
Mesbah, M., Premachandran, U. \& Whitman, W. B. (1989). Precise measurement of the $\mathrm{G}+\mathrm{C}$ content of deoxyribonucleic acid by high-performance liquid chromatography. Int J Syst Bacteriol 39, 159-167.

Olsen, G. J., Matsuda, H., Hagstrom, R. \& Overbeek, R. (1994). fastDNAmL: a tool for construction of phylogenetic trees of DNA sequences using maximum likelihood. Comput Appl Biosci 10, 41-48.

Reysenbach, A.-L., Giver, L. J., Wickham, G. S. \& Pace, N. R. (1992). Differential amplification of rRNA genes by polymerase chain reaction. Appl Environ Microbiol 58, 3417-3418.

Saitou, N. \& Nei, M. (1987). The neighbor-joining method: a new method for reconstructing phylogenetic trees. Mol Biol Evol 4, 406-425.

Schoeffield, A. (1990). Ecological, serological and molecular characterization of halophilic bdellovibrios. $\mathrm{PhD}$ thesis, University of Maryland, Baltimore, MD, USA.

Seidler, R. J. \& Starr, M. P. (1969). Isolation and characterization of host-independent bdellovibrios. J Bacteriol 100, 769-785.

Seidler, R. J., Starr, M. P. \& Mandel, M. (1969). Deoxyribonucleic acid characterization of bdellovibrios. J Bacteriol 100, 786-790.

Seidler, R. J., Mandel, M. \& Baptist, J. N. (1972). Molecular heterogeneity of the bdellovibrios: evidence of two new species. J Bacteriol 109, 209-217.

Snyder, A. R., Williams, H. N., Baer, M. L., Walker, K. E. \& Stine, O. C. (2002). 16S rDNA sequence analysis of environmental Bdellovibrioand-like organisms (BALO) reveals extensive diversity. Int J Syst Evol Microbiol 52, 2089-2094.

Starr, M. P. \& Seidler, R. J. (1971). The bdellovibrios. Annu Rev Microbiol 25, 649-678.
Stolp, H. \& Petzold, H. (1962). Untersuchungen über einen obligat parasitischen Mikroorganismus mit lytischer Aktivität für Pseudomonas Bakterien. Phytopathol Z 45, 364-390 (in German).

Stolp, H. \& Starr, M. P. (1963). Bdellovibrio bacteriovorus gen. et sp. n., a predatory, ectoparasitic, and bacteriolytic microorganism. Antonie van Leeuwenhoek 29, 217-248.

Sutton, D. C. \& Besant, P. J. (1994). Ecology and characteristics of bdellovibrios from three tropical marine habitats. Mar Biol (Berl) 119, 313-320.

Taylor, V. I., Baumann, P., Reichelt, J. L. \& Allen, R. D. (1974). Isolation, enumeration, and host range of marine bdellovibrios. Arch Microbiol 98, 101-114.

Varon, M. \& Shilo, M. (1968). Interaction of Bdellovibrio bacteriovorus and host bacteria. I. Kinetic studies of attachment and invasion of Escherichia coli B by Bdellovibrio bacteriovorus. J Bacteriol 95, 744-753.

Weisburg, W. G., Barns, S. M., Pelletier, D. A. \& Lane, D. J. (1991). $16 \mathrm{~S}$ ribosomal DNA amplification for phylogenetic study. J Bacteriol 173, 697-703.

Williams, H. N. (1979). Cultural, immunologic and ecologic studies of marine bdellovibrios isolated from the Atlantic Ocean and the Chesapeake Bay. $\mathrm{PhD}$ thesis, University of Maryland, Baltimore, MD, USA.

Williams, H. N. (1987). The recovery of high numbers of bdellovibrios from the surface water microlayer. Can J Microbiol 33, 572-575.

Williams, H. N. \& Falkler, W. A., Jr (1984). Distribution of bdellovibrios in the water column of an estuary. Can J Microbiol 30, 971-974.

Williams, H. N., Schoeffield, A. J., Guether, D. G., Kelley, J., Desai, D. \& Falkler, J. W. A. (1995). Recovery of bdellovibrios from submerged surfaces and other aquatic habitats. Microb Ecol 29, 39-48. 